ISSN 0185-0121; e-ISSN 2448-6558; DOI: 10.24201/nrfh.v69i2.3754

\title{
VOCES EN EL CRISOL. ASEDIOS A LAS REESCRITURAS EN ANTÍGONA FURIOSA DE GRISELDA GAMBARO
}

\author{
VOICES IN THE CRUCIBLE. NOTES ON GRISELDA \\ GAMBARO'S REWRITINGS OF ANTÍGONA FURIOSA
}

\author{
Griselda Córdova Romero \\ Instituto Tecnológico y de Estudios \\ Superiores de Monterrey \\ gris.cordovar@gmail.com \\ orcid: 0000-0003-4362-8183
}

\begin{abstract}
RESUMEN: Este artículo explora la noción de reescritura en Antígona furiosa (1986), de Griselda Gambaro. En sintonía con una larga tradición de Antígonas, el texto gambariano se apropia de la tragedia de Sófocles y reelabora fragmentos de obras de otros autores como Marguerite Yourcenar, William Shakespeare y Rubén Darío, así como del último discurso público de Juan Domingo Perón. A este amplio panorama de relaciones intertextuales se suma un cotejo entre Antígona furiosa y Antígona Vélez (1951), de Leopoldo Marechal, que permite, a partir de la recuperación del mito, reflexionar sobre dos períodos clave de la historia argentina del siglo xx: el primer peronismo (1945-1955) y el terrorismo de Estado durante "El Proceso" (1976-1983). Este estudio busca comprender el teatro de Gambaro como artefacto de la memoria, su estrecha relación con el horizonte cultural, social y político argentino, y destacar asimismo el papel central de la reescritura en esta obra en particular.
\end{abstract}

Palabras clave: Griselda Gambaro; reescritura; Antígona; dramaturgia argentina del siglo xx; dictadura militar "El Proceso".

Aвstract: This article explores the notion of rewriting in Griselda Gambaro's Antigona furiosa (1986). In line with a long tradition of Antigones, her play appropriates the tragedy of Sophocles and reelaborates fragments taken from different texts by Marguerite Yourcenar, William Shakespeare, Rubén Darío, and from the last public speech made by Juan Domingo Perón. This broad panorama of textual dialogues is duly examined, but an analysis is also offered between Antígona furiosa and Leopoldo Marechal's Antígona Vélez (1951). The aim here is to compare the mythical interpretation given to two key periods in the history of Argentina in the 20th century: Perón's first presidency (1945-1955), and the terrorism carried out by the State during what was known as "El Proceso" (1976-1983). This study seeks to understand Gambaro's theater as an artifact of memory, to point out the close relationship between her literature and the cultural, social and political world in which she moved in Argentina, as well as to highlight the central role of rewriting in this particular play.

Keywords: Griselda Gambaro; rewriting; Antigone; 20th century Argentinian theatre; military dictatorship "El Proceso".

Recepción: 18 de febrero de 2019; aceptación: 21 de abril de 2020.

D.R. (C) 2021. Nueva Revista de Filología Hispánica Licencia Creative Commons Attribution-NonCommercial (CC BY-NC) 4.0 International 
EN TORNO A LAS REESCRITURAS GAMBARIANAS*

Desde sus primeras publicaciones en los años sesenta del siglo xx hasta sus más recientes obras, la producción narrativa y dramática de Griselda Gambaro (Buenos Aires, 1928) ha cautivado los más diversos intereses de la crítica: sea por su participación en el Instituto Di Tella y sus aportes a la neovanguardia teatral argentina -denominada, en su caso exclusivo, "absurdo gambariano"-1; por su notoria afinidad con el grotesco criollo discepoliano; o por la conformación de una literatura que versa, entre otras cuestiones, sobre la perversión, las dinámicas de poder, la transgresión, la represión y la violencia. A dichos rasgos, estrechamente ligados entre sí, ha de sumarse un gesto reiterado de manera transversal en su obra, que es la reescritura: un sofisticado ejercicio de apropiación y reelaboración de otros textos que abre las puertas a un complejo entramado de referencias no sólo literarias y artísticas, sino también históricas y sociales $^{2}$. No pocos han sido los intentos por comprender esta

* Este estudio es parte de un trabajo más amplio y exhaustivo, una investigación doctoral dedicada a explorar los avatares de las reescrituras en la vasta obra, tanto narrativa como dramática, de Griselda Gambaro. Aquí sólo nos dedicamos a una de sus piezas más emblemáticas, Antígona furiosa, estrenada en Buenos Aires en 1986.

1 Como indica Osvaldo Pellettieri (1997, passim), la neovanguardia, nucleada alrededor del Instituto, tuvo en el teatro argentino de aquellos años tres tendencias fundamentales: la creación colectiva a la manera del living theatre bajo la influencia de las técnicas de Grotowski, el happening y el absurdo. Dubatti (1999) a su vez refiere cómo durante los años sesenta la escena dramática se fracturó entre los "nuevos" realistas, los vanguardistas y quienes buscaban rescatar la tradición vernácula del sainete y la comedia asainetada. Hacia finales de la década del sesenta y antes del golpe militar de 1976, estas tres tendencias confluirían en un pronunciamiento político como crítica al autoritarismo militar -se recordará también el golpe de Onganía en 1966 (pp. 260-265).

${ }^{2}$ Su obra se estrena en 1963 con el libro de relatos Madrigal en ciudad, y la pieza teatral Las paredes. El desatino (1964) será, con un año de diferencia, su segunda publicación también de relatos. Con este título ( $\mathrm{El}$ desatino), que toma de un cuento incluido en la compilación, se conocerá asimismo su segunda obra teatral, de 1965. Además, dicho volumen incluyó un cuento titulado "Las paredes", tal como su primera obra dramática. Como se verá años más tarde, éste será un ejercicio de reescritura interna que retomará al escribir y publicar su obra de teatro El campo (1967) y su cuento "El trastocamiento" (que figura en el volumen Lo mejor que se tiene, de 1998); su obra de teatro Nada que ver (1970) y su novela Nada que ver con 
singular cualidad de su escritura. En su mayoría, tales empresas conducen sus acercamientos con una estricta perspectiva teórica de la textualidad, misma que, desde nuestra postura, conlleva a su vez ciertos límites metodológicos; límites que, en el peor de los escenarios, obligan a elaborar rizomas teóricos que se van alejando de aquello que realmente es, y siempre será, lo importante en la literatura gambariana: el diálogo que establece no sólo con otros textos, propios y ajenos, sino también con la realidad, el contexto.

Varias son las categorías acuñadas para la comprensión de este gesto creativo, la reescritura, cuya discusión ha sido ciertamente extensa ${ }^{3}$. Sin embargo, es posible advertir en este lar-

otra historia (1972); y su cuento "Nosferatu" (incluido también en Lo mejor que se tiene) y una pieza teatral homónima escrita en 1970 y estrenada por primera vez en 1985. A estos ejemplos de intratextualidad (o reescritura de sus propias obras) habrán de sumarse, a cada uno por su cuenta, diversas referencias intertextuales más. Las reescrituras en los textos gambarianos son numerosas, y en ocasiones insospechadas. Véanse, por mencionar tan sólo algunos ejemplos: El viaje a Bahía Blanca (1974), obra que reescribe dramáticamente el cuento "Le voyage à Khonostrov" del polímata francés Boris Vian; Penas sin importancia (1990), como reelaboración paródica de Tío Vania, de Chéjov, y de Trescientos millones, de Roberto Arlt; Dios no nos quiere contentos (1979), novela en la que reconstruye las villas miseria en la Argentina de Videla a la manera de Cándido, de Voltaire, y a partir del mito de Tristán (nombre que recibe el personaje protagónico); La casa sin sosiego (1991), ópera de cámara que recupera fragmentos de una larga lista de autores, entre ellos Elsa Morante, Jean Cocteau, Cyril Connolly, Rainer María Rilke, Ernesto Sábato, Dante Alighieri y Claudio Monteverdi; Después del día de fiesta (1994), novela en la que el personaje de Tristán vuelve, pero ahora a la Argentina contemporánea, en medio de poesía gauchesca, versos de Alejandra Pizarnik, del poema "La sera del dì di festa" ("La noche del día de fiesta", 1820) y de la Oppereti morali de Giacomo Leopardi, y fragmentos del epistolario personal de Paolina Leopardi, hermana del poeta; $\mathrm{La}$ señora Macbeth (2004), en evidente referencia a la tragedia de Shakespeare; y, finalmente, Querido Ibsen: soy Nora (2012), pieza dramática que reescribe "a lo Pirandello" el texto Casa de muñecas de Henrik Ibsen.

${ }^{3}$ En 1967, templada entre las aportaciones semióticas de Saussure y el dialogismo de Bajtín, Julia Kristeva propone que "todo texto se construye como mosaico de citas, todo texto es absorción y transformación de otro texto" (1997, p. 3). Desde su perspectiva, la intertextualidad implicó la convivencia simultánea de dos o más discursos, sin distinguir necesariamente una jerarquía dialógica entre ellos. Posteriormente, Antoine Compagnon (1979) también propuso un estudio de la reescritura pero en términos de citación. Para él, la cita es la práctica principal de un texto y combina tanto el acto de leer como el de escribir; y ya que según Compagnon toda práctica 
go debate la prefiguración de dos posibles sesgos: enaltecer la reescritura como un fenómeno exclusivamente textual y obviar la versatilidad del término para nombrar e incorporar la pluralidad de sus acepciones. En El demonio de la teoría, publicado en 1998 después del fervor de que gozaron las teorías estructuralistas, el crítico francés Antoine Compagnon desglosa de manera puntual lo que teóricamente se había elaborado como una disyuntiva o, en sus propios términos, como una "alternativa intimidatoria”: “...o la literatura habla del mundo, o la literatura habla de la literatura" (2015, p. 115), dos posturas excluyentes que no admitían cruces. Y agregaría en este mismo libro, años después de su clásico estudio anterior sobre la "seconde main", que, limitando la huella bajtiniana al principio de intertextualidad, "nos hemos ido a las alturas... donde la complejidad de las relaciones intertextuales ha servido para eliminar la preocupación por el mundo que contenía el dialogismo” (p. 133). Así, al sobreestimarse las relaciones entre los textos, la teoría tendió a subestimar los lazos referenciales. Por lo tanto, un acercamiento exclusivamente de corte intertextual -pues es de reconocerse y no descartarse su utilidad para señalar y diferenciar procedimientos escriturales peculiares-, habitual por cierto en los estudios críticos gambarianos, implica una lectura ensimismada en categorías que coarta con frecuencia un mayor y necesario alcance interpretativo más allá del reino de lo textual.

Michel Lafon, en su extenso análisis sobre la reescritura en Borges, reconoce por su parte el valor plural del término que empleamos en este estudio. Así, Lafon (1990, p. 10) explica que:

Au début de cette traversée analytique de l'ensemble de la production textuelle de Borges, le terme [réecriture] m'est dicté par un double constat: l'œuvre borgésienne pratique, abondamment et en toute clarté, la citation; elle pratique aussi, non moins abondamment mais d'une manière moins visible, la répétition.

textual es cita, ninguna definición es viable (p. 34). El parteaguas teórico sobrevendría después, cuando GÉRARD GENETTE reencaminara sus primeros acercamientos en Introducción al architexto (1979) hacia Palimpsestos. La literatura en segundo grado (1982), donde planteó los varios grados de copresencia entre textos, noción que permitió entender que estas relaciones se establecen siempre de manera jerárquica, y que de esta jerarquía depende el valor particular de cada procedimiento. 
D'une part, l'utilisation de textes d'autrui, l'érudition; d'autre part, la réutilisation de ses propres textes, leur reconduction. Ces deux pratiques "excessives", non limitatives et non exclusives (la citation peut être citation de soi, la répétition peut être répétition d'un autre, bref la citation peut être répétition et la répétition citation), c'est d'abord cela que je propose d'appeler réécriture.

Se comparte, en este sentido, el doblete del término, puesto que en Gambaro encontramos un tipo de escritura en la que reescribir es también reescribirse a sí misma por medio de distintos géneros para explorar y agotar un mismo tema, un personaje, una anécdota. Al igual que el crítico francés, creemos que las prácticas de la reescritura, sus diferentes expresiones y modos, no se limitan ni se excluyen entre sí, pero también que implican un procesamiento referencial en el que la "citación" y la "repetición" se reconducen hacia una nueva textualidad. De tal modo, nuestro principal interés se centra en el fenómeno de la transformación textual, entendida en un amplio sentido, en sus diversas modalidades y funciones, así como en las prácticas habituales e irrefutables de este ejercicio. Al mismo tiempo, señalamos la estrecha relación de sus obras con el horizonte cultural, social y político argentino, y cómo las apropiaciones literarias desempeñan un papel decisivo en este diálogo.

Por ende, proponemos un acercamiento crítico en el que reintroducir la realidad, la historia y la sociedad, desde la pertinencia y complejidad de la obra misma, fuera imperativo. Bajo esta perspectiva, abrimos camino asimismo para revertir la "alternativa intimidatoria" aludida por Compagnon, y suplantarla por un estudio reivindicativo de la más auténtica motivación gambariana: dialogar con la literatura y con el mundo. Desde este posicionamiento crítico y teórico emprendemos el presente estudio con el fin de explorar in extenso una de las obras medulares de la dramaturgia gambariana, la pieza teatral Antígona furiosa: crisol de voces como la de Shakespeare, Yourcenar, Darío o incluso la de Juan Domingo Perón; heredera de un extendido linaje de Antígonas que resiste el diálogo franco con sus homólogas -la Antígona Vélez de Marechal-; punto de encuentro de ecos literarios, y abrevadero de las grandes discusiones de una época marcada por la dictadura y los crímenes de Estado en Argentina. 
El Furor DE ANTÍGonA

George Steiner (2009) acierta en sostener que la universalidad de la tragedia sofoclea reside en su capacidad para reunir conflictos reiterados en el devenir humano, es decir, "la dialéctica de los sexos, de las generaciones, de la conciencia privada y del bien público, de la vida y de la muerte, de lo mortal y de lo divino” (p. 277). Más allá, podríamos agregar que el mito sobrevive por su capacidad para caminar indistintamente por los umbrales de la otredad desde la empatía, la fraternidad o la sororidad; reescribirlo es, por tanto, epítome de la memoria y antídoto contra el olvido. Pero a pesar del sesudo esfuerzo del crítico francés, el "olvido" del motivo clásico en la tradición iberoamericana ha sido no obstante una de las amonestaciones más extendidas acerca de su estudio: "En cualquier libro de Steiner -dice Griselda Gambaro-, un hombre tan erudito, las culturas de América del Sur no existen" (1999, pp. 81-82). Estos olvidos también son extensibles a las reescrituras de autoría femenina, inclusive dentro de la tradición occidental, al dejar fuera de sus consideraciones a Marguerite Yourcenar ${ }^{4}$.

Revisitar la materia clásica, abundante en temas como valores y personajes, es una exploración artística ya registrada en Gambaro $^{5}$. Si bien algunas influencias mitológicas se retomaron con entrañable afán durante el Romanticismo -y algunas expresiones cada vez menos eufóricas durante los siglos subsecuentes-, ciertos topos de referencia despuntan en cuanto a su apropiación y propagación en distintas expresiones artísti-

${ }^{4}$ Me refiero aquí al relato titulado "Antígona o la elección”, incluido en la colección de cuentos Fuegos, de 1936. Asimismo, se ha reprochado a Steiner el olvido de tres reescrituras españolas: Antígona (1939), La sangre de Antígona (1955) y La tumba de Antígona (1967), de Salvador Espriu, José Bergamín y María Zambrano, respectivamente.

${ }^{5}$ Véanse las relaciones reescriturales entre la pieza teatral Nada que ver (1970) y la novela Nada que ver con otra historia (1972), de Gambaro, la reelaboración que éstas hacen de Frankenstein o el moderno Prometeo, de Mary Shelley, y la presencia de temas adyacentes como el mito prometeico, el grotesco criollo y el álgido debate sobre la lengua de los argentinos. Del mismo modo, véanse algunas continuidades temáticas en la obra de Gambaro: los desaparecidos en la Antígona furiosa y en dos piezas dramáticas de los años noventa, Atando cabos (1991) y La casa sin sosiego (1991). Acerca de esta última, primera y única ópera de cámara de Gambaro, las reescrituras parten principalmente del relato mitológico de Orfeo y Eurídice, así como de los diálogos con textos de otros escritores, mencionados ya en una nota anterior. 
cas y discursos académicos. Tal es el caso del tópico referente a la princesa tebana, Antígona, relato arraigado genéticamente en la tragedia homónima de Sófocles, y en un encadenamiento de reescrituras y variaciones al que también se sumaría Griselda Gambaro con su Antígona furiosa ${ }^{6}$. Escrita en 1986, y estrenada en septiembre del mismo año en el Instituto Goethe en Buenos Aires, se trata de una poderosa pieza teatral concebida en un contexto hondamente conflictivo: un par de años después de terminada una de las dictaduras más feroces en Argentina, marcada por el genocidio y desaparición de aproximadamente treinta mil personas, la opresión mediática y la censura artística, así como por crímenes de lesa humanidad. Junto con su teatro de la década de 1960, $A F$ ha sido una de las piezas más celebradas y estudiadas de Griselda Gambaro en su larga carrera como dramaturga, algo que se demuestra también por su vigencia en las tablas.

El valor del nombre, como dice Pimentel (2012, p. 259), tiene en sí mismo un valor de indicio. Así, decir "Antígona" es apelar a una "constante icónica del mito", a procedimientos literarios, dramáticos o modos de enunciación específicos para la recreación inequívoca del personaje: la insumisión ante la ley, la heroína que dice "no", la rebelde, la encarnación de la rebelión, aquella que desafía la ley, la sacrificada, la virgen inmolada (Capeloa, apud Sicot 2011, p. 818). A ello se suma la importancia que Gambaro concede a otros "temas-valor", presentes en

${ }^{6}$ En adelante, abreviaré el título como $A F$. Citaré la versión de la obra reunida en GAMBARo 1989.

7 Otros acercamientos a la noción de reescritura se han propuesto a partir de las teorías de la literatura comparada y su concepción de las relaciones interartísticas como fenómeno supranacional. Según entendemos a partir de Claudio Guillén (1985), la tematología será la subdisciplina que estudie los temas o argumentos literarios y su recurrencia en otras manifestaciones artísticas. En sus reflexiones, Guillén sostiene que, al retomar un tema, hay en quien cita una voluntad de continuidad, pues valora lo repetido (p. 276). Luz Aurora Pimentel (1993) explica posteriormente cómo "bajo la cobertura de un nombre propio, un tema-personaje es una síntesis de diversos motivos y de temas-valor, ordenados e interrelacionados de tal manera que dibujen un perfil narrativo que le confiera identidad al tema" (p. 221). Entendemos, como indica Pimentel, que el término valor refiere a un conjunto de categorías semánticas que acompañan al tema-personaje, o que pueden aparecer independientemente de él. A estas consideraciones éticas y estéticas de la continuidad deben sumarse aquellas que apuntalan una variación o, como explica Harry Levin, un desplazamiento de la carga temática y su transposición ideológica ( apud Pimentel, p. 130). Las continui- 
Sófocles y otros autores, y que transitan sobre los mismos ejes: el rey loco, la mujer/ princesa loca, el vaticinio sobre la caída del tirano, la búsqueda de la justicia y la verdad. Además, en esta pieza prevalece un juego de relaciones textuales y discursivas -algunas de ellas implícitas, codificadas o sospechosas-, propio de la escritura gambariana, como veremos.

La lectura minuciosa y atenta del argumento clásico en la obra de Sófocles se hace evidente a lo largo de $A F^{8}$. En lo que al argumento se refiere, las distintas unidades de sentido se conservan: a la muerte de los hermanos, Antígona transgrede la prohibición de los ritos funerarios, hecho que desata el careo entre el rey Creonte y la heroína, sentenciada a muerte según la disposición legal. De particular relevancia para estas reelaboraciones serán tres aspectos, a saber: la recuperación del corifeo griego, la compleja expresión de la locura en el personaje de Antígona y la furia como pasión trágica, condiciones todas estrechamente relacionadas entre sí.

Sobre las funciones y características del coro, primero algunos apuntes. Se presume que Sófocles habría escrito un breve tratado de carácter teórico-técnico en el que discutiría cuestiones sobre el coro y su número de integrantes. Aunque el testimonio no se conserva, se atribuyen al poeta trágico algunas innovaciones, como lo es un mayor número de coreutas: de doce, como usualmente se empleaba, a quince. La ejecución del verso dramático alternaba entre la recitación y el canto, reservado este último para el coro. Como unidad dramática colectiva, el coro poseía un adalid, un corifeo, quien acompañaba entre baile y canto composiciones poéticas de "lenguaje muy elevado y con una compleja y muy variada estructura métrico-musical" (Bergua 1982, p. xiv), a la vez que tocaba el aulós. En la comunión de estas características reside su complejidad, pues el coro, como unidad, debe conservar una voz comunitaria y al mismo

dades, variaciones y actualizaciones, en este sentido, se vuelven igualmente valiosas a la hora de interpretar los textos desde el punto de vista de las reescrituras de un tema.

${ }^{8}$ A decir de Susana Reisz (1995), y a "diferencia de otras versiones contemporáneas que se limitan a recoger el núcleo argumental sofocleo apartándose de la literalidad y del registro primigenios, Gambaro parte, al igual que Brecht, de una traducción del original griego, de la que se sirve en forma intermitente y fragmentaria” (p. 95). Ciertamente, Brecht se basa en la traducción de Hölderlin, y a la luz de distintas versiones de Sófocles consultadas, resulta asimismo sugerente y factible el comentario de Reisz sobre Gambaro, aunque no brinde más información al respecto. 
tiempo virtuosamente singular, para así dialogar con los personajes trágicos. En estas confrontaciones constantes se entrevé su función dentro de la tragedia, que, según Kierkegaard (2003 [1843], p. 20) a propósito de la Antígona sofoclea, oscila entre la sustancia épica y el fervor lírico que no logran resolverse en la individualidad de los personajes principales.

En el coro de $A F$ pueden reconocerse algunas de las condiciones del coro clásico con sus respectivas variantes. Su virtud más evidente es que no se trata de un colectivo numeroso, sino de un solo coreuta en escena, que es en sí mismo su propio "vocero" o corifeo. Su función, aun así, persiste, pues se asume como una entidad simultánea y complejamente plural que sintetiza en sí misma otras voces que no pertenecían de manera estricta al coro clásico. En otras palabras: el corifeo gambariano toma la palabra ya como corifeo y voz colectiva, ya como voz de Creonte y símbolo del poder, e incluso, como recurso esporádico, trae a la actualidad de la representación el discurso de Tiresias o de Hemón. Dicha cualidad proteica se simboliza espectacularmente desde la primera acotación, en la que se anuncia cómo "una carcasa representa a Creonte. Cuando el Corifeo se introduce en ella, asume obviamente el trono y el poder" (Gambaro 1989, p. 196). Creonte, como tal, no existe en el escenario, sino que se manifiesta sólo a partir de la dimensión desdoblada del corifeo al ocupar la carcasa. El uso de este artefacto adquiere un amplio sentido: la carcasa, de la voz francesa carcasse, hace referencia usualmente al esqueleto de un animal, aunque su uso es también familiar para aludir al esqueleto humano. Esto implica que, en el contexto de un mito donde "el tema de la sepultura hace vibrar elementales cuerdas del sentimiento público y privado" (Steiner 2009, p. 141), la figura de la carcasa establece estrechas relaciones entre el poder represivo y los muertos (víctimas y victimarios), pero también una analogía entre el poder y un "cuerpo caduco".

Se advierte, con todo, que esta espesura dramática del corifeo contamina la materialización en escena de otros personajes. En $A F$, los diálogos entre las hermanas Antígona e Ismena no se enuncian durante el prólogo -al no haber más episodios, evidentemente-, según lo dispuso la estructura clásica, sino que se suman a la voz de la protagonista: del caudal de su discurso emerge por momentos el conflicto entre las hermanas, así como es Antígona quien también actualiza el relato de los hermanos. A Antígona y Corifeo, con sus respectivos desdoblamientos, 
habrá de sumarse la peculiar presencia de Antinoo, único personaje sin escisiones al que nos dedicaremos en otro momento. Esta dramatis personae tripartita (Antígona, Corifeo, Antinoo) puede deberse a la economía espectacular y escénica que caracteriza las propuestas teatrales gambarianas. Otra hipótesis, me parece, se alienta gracias a otra de las aportaciones que Bergua Cavero (1982) señala como propias del teatro sofocleo: desde Esquilo, dice el crítico, sólo dos actores podían aparecer en escena, mientras que a partir de Sófocles se introdujo a un tercer actor, con lo cual se produjeron "diálogos triangulares, de gran efecto y movimiento" (p. xvii). Esta relación dinámica y triangular entre los personajes, así como la construcción múltiple de sus discursos, promueven en gran medida la densidad dramática característica de $A F$; densidad que, asimismo, se intensificará por las dimensiones reescriturales que desglosaremos adelante.

Sobre la locura y la transgresión, unas palabras más. Frente a otras versiones literarias de Antígona que conservan íntegro el nombre, o aquellas que se regionalizan ("Vélez", "Gónzález", "Guaraní") $)^{9}$, sobresale el provocador epíteto del personaje gambariano: furiosa. Rómulo Pianacci (2015, p. 98) sostiene que este adjetivo puede remitir al poema épico Orlando furioso (1532) y al travestismo que Virginia Woolf después desarrolló en su Orlando (1928). El travestismo al que alude el crítico -aleccionado por el artículo de Ana María Llurba que cita líneas adelante- ${ }^{10}$ haría referencia a la construcción de un personaje femenino que transgrede los valores de un sistema de poder androcéntrico. A esta lectura acerca del furor épico podría sumarse el propio furor trágico, entendido como

la consecuencia de un dolor inicial y que constituye el estado pasional o emocional necesario para cometer el nefas, el crimen

${ }^{9}$ Las obras referidas son la Antígona Vélez del argentino Leopoldo Marechal, la Antígona González de la mexicana Sara Uribe y la Antígona Guaraní del paraguayo Víctor Sosa, donde el uso de un apellido o un epíteto busca regionalizar el tema clásico.

10 No comparto, sin embargo, la aseveración de Llurba cuando dice que Gambaro, "enrolada en el feminismo de la diferencia, hace una lectura y una posterior reescritura de la leyenda [sic] marcadamente feminista" (1998, p. 23). Una es la lectura fiel que Gambaro hace del drama sofocleo (que no puede etiquetarse anacrónicamente como feminista), otra la interpretación de la crítica contemporánea hacia este mito clásico en términos de feminismo y teoría de género. 
nuclear de toda tragedia. Es cierto que el furor es sentido por casi todos los héroes de los dramas: se vuelven furiosi Hércules y Atreo, furiosae son Medea, Fedra y Clitemnestra (Pérez 2011, p. 154).

Según Leonor Pérez Gómez, el furor es una de las pasiones clásicas que caracteriza la locura trágica o locura pasajera, impulso que eventualmente conduce a la transgresión. Sin embargo, no por ello, continúa Pérez Gómez, el conflicto se reduce a la oposición entre el furor y la ratio, ni implica que quien actúe motivado por la furia lo haga sine ratione; asimismo, el producto de la íntima ligazón entre furia y locura no debe confundirse con la dementia, la amentia o la insania. Caso particular será el de las Furiae -o Erinias, en la tradición griega-, cuya función en la mitología romana consistía en atormentar a quienes perpetraran crímenes de diversa índole, para vengar así a las víctimas de sus actos. Esto marcará las pautas para comprender el sentido doblemente articulado de la furia en $A F$ : como acto de transgresión ante la injusticia (pública, del Estado, de las leyes del hombre) y como instrumento de la memoria. De esta manera Gambaro, mediante ingeniosos procedimientos de apropiación e intervención, parece cancelar y superar aquello que Bertolt Brecht (1963 [1954]) denominó la "intimidación por los clásicos": una postura dramática "falsa", decadente y superficial, una renovación formalista que impide una representación viva y humana de la tragedia griega ${ }^{11}$.

\section{DEL CANTO AL SILENGIO: LA TRANSFORMAGIÓN}

La Antígona furiosa de Griselda Gambaro prefigura la crónica de una pausa, un instante dramático que condensa en un acto único la escena del ahorcamiento y muerte de la heroína griega. La acción se inicia en el escenario con "Antígona ahorcada. Ciñe sus cabellos una corona de flores blancas, marchitas. Después de un momento, lentamente, afloja y quita el lazo de su cuello, se acomoda el vestido blanco y sucio. Se mueve, canturreando" (Gambaro 1989,

11 BRECHT advierte que "si nous nous laissons intimider par une conception fausse, superficielle, décadente, petite-bourgeoise du classicisme, nous ne parviendrons jamais à donner des représentations vivantes et humaines des œuvres classiques. Pour leur manifester le respect véritable auquel elles ont légitimement droit, nous sommes tenus de démasquer le respect hypocrite et faux qui ne les sert que du bout des lèvres" (1963 [1954], p. 579). 
p. 197). Retirar la soga del cuello y la corona marchita sobre el cabello representan aquí los dos signos inequívocos de la princesa que ha cometido ya el nefas y, voluntariosa, ha recibido el castigo impuesto por Creonte. Si en el texto clásico se alternan las intervenciones del coro (párodos y estásimos) y de los personajes (episodios) con los diálogos líricos, en $A F$ esta dinámica se concentra en un acto y en pocos personajes. Este tercer tipo, los diálogos líricos, se intercalan "en un episodio o sustituyen a un estásimo..., en los que uno o varios personajes dialogan con el coro o el corifeo, pero lo hacen cantando, pues la tensión dramática así lo requiere" (Bergua 1982, p. xiv). Por lo tanto, la fuerza trágica del texto gambariano se potencia al tratarse enteramente de un diálogo lírico en el que se articula un debate sobre el poder y la locura, la justicia y la vejación.

En el diálogo lírico construido para representar la elongación de la muerte de Antígona, confluyen las voces de otros personajes clásicos en las que se percibe una curiosa sintonía de gran parte de los motivos medulares del Hamlet, de Shakespeare. Tales motivos se insertan manteniendo una estricta simetría, pues los primeros diálogos de la Antígona gambariana se corresponden con el canto de locura de Ofelia, mientras los últimos, previos a su muerte, reproducen las palabras de Hamlet. La primera intervención en la obra de Gambaro es del corifeo, en un tono irónico, con una referencia nada ingenua: "¿Quién es ésa [refiriéndose a Antígona]? ¿Ofelia?” (1989, p. 197). Este diálogo marca dramáticamente la primera aparición en escena de Antígona, al entonar un canto fúnebre, en una clara referencia a la locura del personaje shakesperiano, una vez muerto su padre. Así, en la versión inglesa se lee:

Ophelia: [Sings] He is dead and gone, lady.

He is dead and gone.

At his head a grass-green turf,

At his heels a stone

(Shakespeare, IV, 5; 2015 [1609], p. 496).

Y en la versión de Gambaro se registra:

AnTígona (canta): Se murió y se fue, señora;

Se murió y se fue;

El césped cubre su cuerpo,

Hay una piedra a sus pies (1989, p. 197). 
El vínculo con el personaje de Hamlet se complementa con las palabras de una Antígona que, furiosa por desentrañar la verdad y desarticular las injusticias del poder, se refiere a su propia muerte transfigurando también los diálogos sofocleos: "Nací, para compartir el amor y no el odio. (Pausa larga) Pero el odio manda. (Furiosa) ¡El resto es silencio! (Se da muerte. Con furia)" (p. 217) ${ }^{12}$. Este diálogo debe todo sentido, de manera evidente, a las últimas palabras del personaje inglés, quien antes de morir profiere: "The rest is silence" (Shakespeare, V, 2; 2015 [1609], p. 672). El homenaje a estos personajes deja ver una atadura significativa, donde la locura de Ofelia y la venganza del príncipe de Dinamarca se conjugan ante un dolor común, es decir, la muerte del padre y, en un sentido más amplio, la búsqueda de justicia para los muertos. La locura conduce y da sustento a los argumentos dramáticos, pues condiciona y cataliza las acciones de Antígona y Hamlet, movidos a cometer el nefas "racional". Lo mismo para Creonte y Ofelia, en quienes la locura se juzga por los demás personajes como "falta de razón". Mientras la princesa tebana actúa motivada por la locura furiosa como una pasión trágica, el príncipe danés monta un personaje de sí mismo, un artificio discursivamente ingenioso.

Otros discursos presentes en la obra gambariana abonan a crear este amplio panorama sobre la locura, el crimen de Estado y la memoria del pueblo. Desde el inicio, los personajes se encargan de establecer y externar sus distancias o cercanías no sólo con los muertos, Eteocles y Polinices, sino -y a partir de lo anterior- con el poder. Creonte se asume como rey y dictador de las leyes de los hombres, mientras Antinoo y Corifeo se postran ante él en una caravana de alabanzas. Antígona, por su parte, no desatiende los fervores debidos a sus padres, Yocasta y Edipo, a sus difuntos hermanos, o a su hermana Ismena. El corifeo, entonces, decidido a amonestar a la angustiada Antígona y burlarse de su linaje, pronuncia: "Está triste, / ¿qué tendrá la princesa? / Los suspiros escapan de su boca de fresa" (Gambaro 1989, p. 204). Los versos citados en voz del corifeo son una innegable referencia a la "Sonatina" de Rubén Darío. Pero el

12 Recordemos que la primera parte en este diálogo de la Antígona gambariana se corresponde con el diálogo de la Antígona de Sófocles, cuando la heroína resiste los obstinados juicios de Creonte sobre perpetuar el odio a los enemigos aun después de la muerte, apelando a que no ha nacido

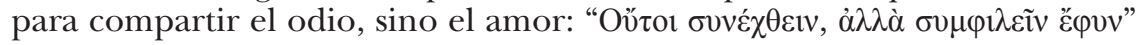
(v. 523; 2002). 
estilo cuidado y lustroso del poeta modernista, con sus expresiones refinadas, sugerentes y evocadoras, encuentra cabida en la obra no con fines plásticos ni musicales, sino como medio para satirizar y burlar el lamento de la princesa, infantilizarla, negar legitimidad a su audiencia. A este uso parodiado de la poesía rubendariana se suma en consecuencia otro terceto, en palabras también del corifeo, pero esta vez invención de Gambaro: "Si se hubiera quedado quieta / sin enterrar a su hermano / con Hemón se hubiera casado" (id.). En voz de Antígona, la otredad textual se dignifica, recobra sentido; en la de Creonte, Antinoo o el corifeo, no obstante, el sentido se trastoca, se parodia hasta el absurdo.

En esto reside el principal contraste entre ambos personajes: Hamlet se viste de locura cuando lo que subyace es el amor por el padre muerto, en tanto que Antígona será siempre considerada la heroína trágica que amó como una loca a su hermano, por quien transgredió la ley. La reiterada insistencia en la locura de Antígona se redimensiona luego desde una lectura extratextual -que también sostiene Ángel Vilanova (1999, p. 144)-, debido al mote de "locas" con el que la dictadura militar de los años setenta buscó deslegitimar a las asociaciones civiles Madres de Plaza de Mayo y Abuelas de Plaza de Mayo, tras exigir el regreso con vida de sus familiares desaparecidos durante "El Proceso". A esto se suman también los cerca de quinientos "apropiados", es decir, hijos de las activistas secuestradas, y posteriormente asesinadas, que nacían dentro de los mismos centros de detención ${ }^{13}$.

Y mientras Antígona actúa pragmática e inmediatamente movida por la furia, Hamlet, loco ingenioso, maquina artificiosamente una trampa discursiva: la metaobra de teatro La muerte de Gonzago, que al presentarse frente al ahora rey Claudio tiene por intención transfigurar su rostro para develar así la verdad sobre el asesino del padre de Hamlet. "O, my offence is rank, it smells to heaven. / It hath the primal eldest curse upon't, /

13 Entre las campañas emprendidas para la reunificación de los nietos con sus familias, se puede mencionar el "Teatro por la Identidad": movimiento conformado por dramaturgos, actores y directores en estrecha relación con la asociación civil Abuelas de la Plaza de Mayo, cuya finalidad era crear una herramienta artística y política para sensibilizar a la sociedad sobre la sustitución de identidades durante el período dictatorial. El nombre, obra teatral de Griselda Gambaro, forma parte del ciclo dramático de dicha campaña. 
a brother's murder" (Shakespeare, III, 3; 2015 [1609], p. 414), pronuncia con remordimiento Claudio, en un recurso discursivo metaficcional y tematológico bien conocido: el hermano asesinado puede ser tanto Osiris como Remo o Absirto, tanto Abel como Polinices. La metateatralidad en Hamlet sostiene que la obra, y la obra incluida en la misma, descansa sobre la conciencia de su propia teatralidad, en el entendido de que los personajes comprenden también esta condición y que, por lo tanto, la "vida" dentro y fuera del diálogo dramático es igualmente vista como "teatralizada" (Abel 1969). En AF, Gambaro no recurre al metateatro en su acepción más común (la obra dentro de la obra), sino a partir de la referencialidad literaria (la reescritura como acto reflexivo $)^{14}$, lo que le permite mostrar, desde ese punto, la materialidad del mecanismo teatral. Incluir Hamlet sería la prueba más evidente de ello, por no mencionar ya el drama sofocleo. Podría sugerirse entonces que, así como el teatro isabelino o el barroco español, el de los griegos o incluso el brechtiano, Gambaro comparte la noción del theatrum mundi: tópico literario que entiende el mundo como un gran escenario, y el teatro como un mundo en representación. Sobre estos encuentros y desencuentros de reescrituras debemos decir que, aunque rigurosamente no se prefigure en $A F$ una obra dentro de otra, como en Hamlet, quizás en el fondo la obra de Gambaro represente en sí misma su propia versión de La muerte de

${ }^{14}$ Sostenemos que las reescrituras, como ejercicio que concierta tanto la lectura como la escritura, devienen en una conciencia reflexiva sobre el acto de creación artístico y literario. Proponemos también que esta práctica textual establece una forma específica de interactuar con el objeto artístico y de interpretarlo, lo que puede entreverse en la manera en que sus elementos se relacionan entre sí: es decir, hay una relación específica entre aquello que se reescribe -ya sea que se cite, se reelabore o parodie- y aquello que lo contiene. En este sentido, la reescritura comulga con una cualidad inherente a las reelaboraciones de corte metatextual, la noción de comentario. En otras palabras, se trata de una relación "que une un texto a otro texto que habla de él sin citarlo (convocarlo), e incluso, en el límite, sin nombrarlo" (GENETTE 1989, p. 13). Y aunque en algunas reapropiaciones de Gambaro no se cite o no se nombre el hipotexto/ intertexto, hay que destacar que en otros muchos casos de reescrituras Gambaro evidencia ante el lector el texto aludido y establece que esa relación es decisiva para una interpretación cabal. De esta manera, en ambos casos (el no citar o convocar, o el nombrar los indicios textuales) un rasgo se conserva: la relación crítica con lo reescrito. A ello debe agregarse la relación crítica con lo real y la dimensión histórica del mundo representado que la "alternativa intimidatoria" buscó suprimir, como vimos, en aras de la autonomía de la literatura. 
Gonzago: es decir, un artilugio teatral para visibilizar verdades y conmover, con ellas, a sus espectadores.

El diálogo lírico entre el corifeo y los personajes, como se dijo, se caracterizó en la tragedia clásica por realizarse mediante el canto, para así sostener la tensión dramática. Ofelia canta una vez muerto su padre, como signo inequívoco de la locura que se desborda más allá de la razón, mientras Hamlet adopta estratégicamente el canto como signo inconfundible aun cuando su objetivo es el silencio que precede a la revelación de la verdad. El canto clásico se transfigura en la tragedia inglesa en un canto reservado para la legítima locura de Ofelia y para la locura fingida de Hamlet, y llega como un eco hasta $A F$. Amplio sentido tiene que la Antígona gambariana complete su periplo discursivo de la locura ofélica (una locura irracional y desmedida, en su primera aparición en escena) hacia la exclamación final hamletiana, donde el silencio marca la verdad final sobre Antígona, muerta/ desaparecida en vida, silenciada como los desaparecidos contemporáneos de la obra de Gambaro.

\section{Antinoo o el MUerto SUblime}

Invariablemente, todas las vías intertextuales conducen a Sófocles, y por lo que se analizó en apartados anteriores, la lectura de Gambaro ha demostrado ser atenta ${ }^{15}$. Las recuperaciones y el resurgimiento del mito pueden pensarse como una expresión del Zeitgeist del siglo xx, ya que, como lo explica Steiner, el texto sofocleo está íntimamente relacionado con períodos de agitación social y política -i.e. períodos de guerra y posguerra, represiones políticas, períodos dictatoriales y genocidios. Sin duda, estas condiciones en su conjunto forman parte de un horizonte cultural y artístico del que abreva $A F$ en mayor o

${ }^{15}$ Por lo demás, establecer una relación entre las reescrituras europeas de Antígona, para así llegar a la propuesta literaria de Griselda Gambaro, podría también resultar provechosa, sobre todo si se toma en cuenta, primero, su formación como dramaturga y, segundo, su afiliación en los años sesenta al Instituto Di Tella, epicentro de la vanguardia artística y punto neurálgico para el espacio teatral argentino, desde donde se catapultó su dramaturgia y se discutieron las principales tendencias en las artes escénicas: Grotowski, Artaud, Pinter y, especialmente, Brecht, quien reelabora el mito en 1948 con su pieza Antigone. A ello se suma el amplio recibimiento de la Antigone de Jean Cocteau, escrita en 1922, cuya primera edición en español vio la luz en Argentina en los años cincuenta. 
menor medida, que no deben excluirse al momento de pensar en los orígenes de esta singular apropiación. Aunque dentro de este inconmensurable horizonte es importante señalar una última apuesta posible, aún sin explorar, que es la relación textual entre la tragedia gambariana y la prosa de Marguerite Yourcenar.

En Fuegos (1936), conjunto de prosas breves, Yourcenar reelabora relatos de distintos personajes míticos. Allí aparece "Antígona o la elección", escrito que versa sobre la gran aspiración de la heroína con "cabellos de loca" por hacer justicia, directiva que determina todos sus actos y empresas. En otros momentos de su escritura, Gambaro demostrará ya su simpatía hacia Yourcenar y su escritura ${ }^{16}$, pero el indicio que más nos interesa se forja gracias a la inclusión de este personaje particularmente inusual: Antinoo, joven bitinio y amante del emperador Publio Elio Adriano, muerto en las profundas aguas del Nilo. $\mathrm{Su}$ presencia en el arte y la cultura se encumbra gracias a los esfuerzos del emperador por preservar su memoria a través de la numismática, la arquitectura, la escultura, incluso la astronomía. En la cartografía literaria, referente insoslayable será la novela Mémoires d'Hadrien (1951), de Yourcenar, pródigamente difundida en el panorama hispanolector a partir de la primera traducción que Julio Cortázar hiciera en 1955 para la Editorial Sudamericana.

La novela se centra en las memorias epistolares del emperador Adriano, a la manera de una "méditation écrite d'un malade qui donne audience à ses souvenirs" sobre el arte, la guerra, la política, y su desmedido amor por el joven Antinoo. En voz, aunque ficticia, de un retirado monarca "qui n'a plus l'énergie nécessaire pour s'appliquer longuement aux affaires d'État" (Yourcenar 1974, p. 29), la muerte del amante esclavo

16 En Escritos inocentes, GRISELDA GAMBARo expresa acerca de esta otra escritura: "Hace días releí la frase de Marguerite Yourcenar: «Toda felicidad es inocente». Nada más cierto. Pero también ninguna inocencia capaz de generar más culpa" (1999, p. 13). Sobre esta referencia a la referencia, dos comentarios: uno, que la escritora argentina retoma la cita de Alexis o el tratado del inútil combate, breve novela escrita en 1929 por Yourcenar; otro, que recuerda un tema obsesivo en la literatura de la escritora argentina, es decir, la conciencia de una escritura que no habla de lo bello, y que construye por medio del discurso una sospechosa "inocencia" textual, tal como puede percibirse en el título irónico del libro-diario del que retomo esta cita. 
se describirá minuciosa y dolorosamente por la exquisita prosa de Yourcenar:

La mort d'Antinoüs n'est un problème et une catastrophe que pour moi seul. Il se peut que ce désastre ait été inséparable d'un trop-plein de joie, d'un surcroît d'expérience, dont je n'aurais pas consenti à me priver moi-même ni à priver mon compagnon de danger. Mes remords même sont devenus peu à peu une forme amère de possession, une manière de m'assurer que j'ai été jusqu'au bout le triste maître de son destin. Mais je n'ignore pas qu'il faut compter avec les décisions de ce bel étranger que reste malgré tout chaque être qu'on aime (p. 189).

A causa de intrigas palaciegas o de un fatal accidente, la muerte del amante (que es todos los amantes a la vez) es sitiada por diversas hipótesis. La más ampliamente extendida -la más poética quizás-, adoptada en Memorias de Adriano, refiere a un posible sacrificio por amor: al ser Adriano desahuciado por el oráculo, un astrólogo aconseja a Antinoo que su muerte en el Nilo habrá de brindar años prósperos y larga vida al emperador, más allá del plazo vaticinado. El amor desmedido por el amante muerto y el despliegue de poder del doliente establecen parámetros textuales desde los cuales es posible interpretar la amplia recuperación de este personaje en el arte, y que ciertamente no forma parte del ciclo tebano o de cualquier otra reescritura sobre Antígona. En $A F$, Antinoo es el único personaje que no se desdobla en el escenario, como sí lo hacen Corifeo/ Creonte o Antígona/ Ismena. Y en este diálogo triangular, propio del estilo dramático sofocleo del que hablamos anteriormente, Antinoo cumple junto con el corifeo la función de amonestar al héroe trágico, posicionándose del lado de las voces públicas: detenta la opinión común y secunda la voz en el poder. En Gambaro, Antinoo, quien fuera digno de grandiosas honras fúnebres, es rebajado a "esclavo" del poder, una figura deleznable, un indigno frente a la heroína:

Antígona: Loco es quien me acusa de demencia.

Corifeo: No vale el orgullo cuando se es esclavo del vecino.

Antígona (señalando a Antinoo, burlona): Este no lo es, ¿vecino?

Ni vos.

Antinoo (orgulloso): ¡No lo soy!

Corifeo: ¡Sí! 
Antinoo: ¡Sí lo soy! (Se desconcierta) ¿Qué? ¿Vecino del esclavo o esclavo del vecino? (1989, p. 203).

Sublimado por los asedios amorosos del emperador, Antinoo no puede aproximarse a -o ser "vecino" de- las tragedias y desgracias del esclavo que, contrario a él, no goza de fortuna alguna. Su experiencia, en cuanto si es "vecino del esclavo" o "esclavo del vecino", contrasta con los muertos nada sublimes de $A F$. En el texto clásico, la noción de los muertos que valen más que otros -Eteocles más que Polinices- es fundamental. El Antinoo de Memorias de Adriano, sublime y digno de todos los funerales, acentúa por contraste -y es una desproporción sobre todo ética- el trato indigno que reciben los muertos en AF: Polinices, el hermano de Antígona, a quien se le niega sepultura y, en un sentido más lato, los muertos y desaparecidos de la represión en Argentina.

De esta manera, a partir de la ausencia de certezas (el desaparecido sin cuerpo, sin tumba), los muertos de $A F$ no tendrán un panteón ni mausoleos (como el Antinoeion en Tívoli en honor al joven bitinio), cielos estrellados en su honor (la constelación de Antinoo, como parte de la constelación de Aquila), o ciudades nombradas después de ellos (la Antinoópolis), como hará el emperador romano tras la muerte de su amante esclavo. De cierta manera, la configuración paródica e irónica de Antinoo -junto con el corifeo- manifiesta la voluntad de romper con la solemnidad de las representaciones de los clásicos, tal como advirtió Brecht, pues enfatiza justamente las relaciones problemáticas entre lo risible -aunque grotesco-y la seriedad. Así, la comunión del humor y de la dignidad -Antinoo y Antígona, respectivamente- ${ }^{17}$ no se excluyen del texto gambariano, lo que permite plantear nuevas variaciones del modelo clásico y recrear el conflicto humano de la tragedia con nuevos acentos, más allá de sus características puramente formales.

17 BRECHT criticó duramente cómo la recuperación de los clásicos tendía a ser seria y "falsa": "comme si humour et dignité vraie s'excluaient!" (1963 [1954], p. 579). De esta manera defendería el "admirable humor" de Goethe en su Fausto, con lo cual señalaría que esta condición no está reñida con la caracterización majestuosa empleada para su representación. 
Reunir en la literatura texto y contexto, sin ensimismarse exclusivamente en su propia especificidad estética, dirá Gambaro, evita la conformación de un arte gratuito, complaciente. Así, entiende que aun cuando "el arte nunca ha servido para atenuar los horrores del mundo" ayuda a reconocerlos y clarificarlos (cf. Roffé 1999, pp. 104-106). Y si en los años sesenta su obra fue erróneamente recibida como "escapista" o ajena al contexto argentino altamente politizado, hoy se comprende como una postura artística crítica ante los discursos políticos oficiales. Para mayores precisiones en este tenor, llama la atención que, además del horizonte político que suponen los años de "El Proceso" (1976-1983), la sombra del tercer período peronista acecha igualmente el crisol textual de la Antígona furiosa de manera codificada.

La locura de Antígona se diferencia de la locura por el poder, punto en que se centra la última reescritura rastreable en $A F$ y que recae en la figura de Creonte. Como reconoce Mabel Parra de Ruiz (2001, p. 129), el Creonte gambariano fusiona en el diálogo dramático uno de los discursos más emblemáticos que Juan Domingo Perón profiriera desde los balcones de la Casa Rosada, el primero de mayo de 1974. Frente al grupo de Montoneros, que lo confrontan a la voz de "¿qué pasa, qué pasa, qué pasa, general, que está lleno de gorilas el gobierno popular?", Perón inició su discurso de la siguiente manera:

Compañeros, hoy, hace veintiún años que en este mismo balcón, y con un día luminoso como el de hoy, hablé por última vez a los trabajadores argentinos. Fue entonces cuando les recomendé que ajustasen sus organizaciones, porque venían días difíciles. No me equivoqué, ni en la apreciación de los días que venían, ni en la calidad de la organización sindical, que a través de veinte años, pese a esos estúpidos que gritan... [Interrumpen con protestas] Decía que a través de estos veintiún años, las organizaciones sindicales se han mantenido inconmovibles, y hoy resulta que algunos imberbes pretenden tener más mérito que los que durante veinte años lucharon (apud Reato 2014, s.p.).

Esto se reproduce especularmente en el drama en voz del corifeo, en su función de voz pública, con el siguiente diálogo: "Y se insultaron. Creonte lo llamó estúpido, iy Hemón le 
dijo que hablaba como un imberbe!" (Gambaro 1989, p. 208). Ese día en la Plaza de Mayo marcó un punto de quiebre entre las organizaciones peronistas y sindicalistas, y aquel que no era ya el mismo líder popular de los años cuarenta -recordemos la figura de la carcasa-; de la misma manera, también supuso un momento histórico en la política argentina en cuanto que sería el último período peronista -con Perón aún presenteantes de instaurarse la próxima dictadura. La reacción de los militantes durante el mitin provocó enfrentamientos y su retirada de la plaza. Montoneros, como organización guerrillera afiliada a la izquierda peronista, habría recibido apoyo de Juan Domingo Perón desde 1970 hasta 1974. Eventualmente, la agrupación sería desmantelada durante el ascenso de la dictadura, ya en 1976. Lo que se aprecia en el texto de Gambaro es, así, la captura instantánea de un instante cardinal para Argentina. Perón, tal como Creonte a Hemón, el padre al hijo, había desacreditado a Montoneros en su propio movimiento, lo había abandonado: "Antinoo: ¡Habló muy bien Hemón! / Corifeo: ¡También Creonte! Dijo: Sólo confío en quienes obedecen. No quebrantarán la ley" $(i d$.).

La transfiguración de la versión gambariana de Creonte, caracterizada por el paternalismo y engrosada con un tono irónico, se enraíza y codifica en la figura de Perón y los grupos filiales a su partido desde antes de su tercer período presidencial. Baste recordar, verbigracia, algunas de las máximas del justicialismo que dictó el general ${ }^{18}$, o la distribución de lecturas infantiles propagandísticas ${ }^{19}$ en la década de 1950. Un par de décadas más tarde, a su regreso a Argentina después de su exilio en España, Perón convocaría el 8 de septiembre de 1973 a las distintas facciones peronistas de izquierda y derecha que diariamente entraban en conflicto. En su papel de líder político, Perón expresó en dicha reunión: "Yo hago aquí de padre eter-

18 Véase en este caso la novena de las "Veinte verdades del justicialismo peronistas": "La política no es para nosotros un fin, sino solo el medio para el bien de la Patria, que es la felicidad de sus hijos y la grandeza nacional"; o la decimosegunda: "En la Nueva Argentina los únicos privilegiados son los niños" (Perón 1958, pp. 22-23).

19 Cf. Niños felices. Libro de lectura para primer grado superior (DoMíNGUEZ 1953). El libro compilaba poemas, adivinanzas y relatos cortos que exaltaban los valores peronistas y su proyecto justicialista en la Nueva Argentina, de donde extraigo estos versos: "Gracias a Evita, que tantas / cosas nos dió con amor, / y gracias a la justicia / del presidente Perón” (p. 116). 
no. La misión mía es la de aglutinar el mayor número de gente posible... No soy juez ni estoy para dar la razón a nadie" ${ }^{20}$. La actitud de Perón durante la entrevista con los dirigentes, sostienen Lucrecia Teixidó y Sergio Bufano, fue de una "ironía subyacente en muchos de sus comentarios" (2015, p. 70); y durante ésta, entre otras ocasiones, se gestaría el gradual desapego del general hacia Montoneros -de ahí las "veinte advertencias", subtítulo con que estos estudiosos orientan su investigación historiográfica. Sostienen, además, una hipótesis sin precedentes: que la Triple A no había sido ideada únicamente por José López Rega -apodado "el Brujo" por su afinidad al esoterismo-, sino que Perón se involucraría igualmente en la creación de esta célula parapolicial que perseguiría a la izquierda radical.

La acción de la pieza teatral transcurre entre el ahorcamiento y la muerte de la heroína, entre la princesa con su corona de flores marchitas, soga al cuello, y el silencio antes del arrebato final con furia. En medio, se hilvanan los debates y las referencias textuales que dan forma y refuerzan el tema clásico, lo actualizan según las condiciones del contexto argentino y su repetición en otros tiempos, otros espacios. La escritura se construye como un eterno presente que se prolonga en el espacio dramático, como ejercicio contra el olvido y la desaparición. "Escribimos para no desaparecer", dice Elena Poniatowska (1991), con el afán de encontrar las consonancias de la palabra, más que las distancias: "Somos las Locas de la Plaza de Mayo en torno a quienes se hace el silencio todos los jueves" (p. 315). La composición dialógica y contrastante de $A F$ reúne justo las grietas y la transición entre dos momentos políticos históricos en Argentina: la historia peronista enmarcada soterradamente por un mandatario que pronto tampoco estaría ya capacitado para los asuntos del Estado (como Adriano), y por el punto de quiebre que implicó la última dictadura militar. Y en esta consonancia de escrituras contra el olvido, la de Gambaro se suma, en una visión amplia y crítica, con una heroína furiosa: una que "a los ojos muertos de Edipo resplandece sobre millones de ciegos"; una, cuya "pasión por el hermano putre-

20 Más adelante se lee: "Yo estoy para llevar a todos, buenos y malos, porque si quiero llevar sólo los buenos voy a quedar con muy poquitos y en política con muy poquitos no se puede hacer mucho... Muchas veces llega un tipo al que le daría una patada y le tengo que dar un abrazo. Pero la política es así, es un juego de utilidad, tolerancia y paciencia”. Retomo la transcripción de las notas taquigráficas de Teıxıdó y Bufano 2015 (pp. 70-71). 
facto calienta fuera del tiempo a miríadas de muertos". Miríadas, como diestramente expresa Yourcenar (2016, p. 114) que finalmente se traslucen en el discurso de la princesa gambariana, quien "siempre" querrá enterrar a Polinices, "aunque nazca mil veces y él muera mil veces" (Gambaro 1989, p. 217).

\section{Ascenso y Caída: de Marechal a Gambaro}

En el marco de las actividades para conmemorar el Día Nacional de la Memoria por la Verdad y la Justicia, la vigencia del motivo clásico se patentiza notoriamente. Prueba de ello fue la presentación de Antígona en tres actos el 23 de marzo de 2017, en el Museo de la Memoria, en Buenos Aires. Se trató de una intervención teatral con la dramaturgia y dirección de Alejandra Gómez y el acompañamiento del Quinteto de Cuerdas de la Municipalidad de Rosario. La pieza se caracteriza por conjugar en un singular montaje tres Antígonas, es decir, la de Sófocles, entintada con la de Leopoldo Marechal y la de Griselda Gambaro. Esta performance, dice Ulises Moset (2017), podría inscribirse en la propuesta dramática del Teatro por la Identidad ${ }^{21}$. El sitio elegido para dicha intervención fue, asimismo, significativo: la antigua Escuela de Mecánica de la Armada, también conocida Escuela de Suboficiales de Mecánica de la Armada o ESMA, predio de 17 hectáreas que desde 2004 se resignifica y nombra "Espacio para la Memoria y para la Promoción y Defensa de los Derechos Humanos", y que fungió como el mayor centro clandestino de detención, tortura y exterminio una vez instaurada la presidencia de facto de Jorge Rafael Videla el 24 de marzo de 1976.

Por cuestiones obvias que tienen que ver con circunstancias y tiempos históricos distintos, la Antígona Vélez (1951) -en adelante, $A V$ - de Marechal se rodea de otros intereses artísticos, sociales y culturales diferentes a los que asediaron el argumento y la representación de $A F$ de Gambaro. Sin embargo, a pesar de las distancias, subyace en ambas una coyuntura temática -aunque muy subterránea-: la figura del peronismo, en su primera y

${ }^{21}$ Como lo indicamos en la nota 13 (cf. supra), se trata de un movimiento en el que Griselda Gambaro ha colaborado con una de sus obras de los años ochenta, El nombre: breve monólogo dramático sobre las ambigüedades y contradicciones de un personaje y los nombres que le son impuestos, en referencia a los casos de sustitución de identidades durante la dictadura. 
tercera épocas. Si bien Gambaro no parece dialogar con la pieza marechaliana, llama la atención el tema comunicante entre los textos, y cómo, cada uno a su manera, constituye una ventana con miras a fases distintas de un movimiento político que marcó hondamente a la sociedad argentina desde mediados de la década de los cuarenta. Las condiciones más importantes en torno a la producción y representación de $A F$ han sido ya esbozadas; asimismo, se sugirió en qué puntos del argumento dramático puede rastrearse el discurso político peronista. Sobre $A V$ de Marechal se sabe que su estreno fue el 25 de mayo de 1951 en el Teatro Nacional Cervantes, con la escenografía de Gregorio López Naguilla, la actuación de Fanny Navarro como Antígona y la dirección en manos de la contraparte tanguera de los hermanos Discépolo, Enrique Santos, también compositor, músico, dramaturgo y cineasta. Un primer estreno se vio coartado ese mismo año, después de que Navarro perdiera el único manuscrito que Marechal tenía preparado. Una reescritura de la pieza le fue encomendada a Marechal a petición personal de Eva Perón, la "Antígona de los Toldos", como la llamó el historiador y periodista argentino Fermín Chávez. La adhesión de Marechal al justicialismo peronista, impulsado por la simpatía hacia los sectores más populares de la Argentina, se lee en la transfiguración de una heroína preocupada por los desheredados o "descamisados", como los nombraba Eva.

En la versión criolla de Marechal, el nombre de la heroína permanece explícito ante el lector o espectador, e incluso habla de sí misma en tercera persona como Antígona Vélez. A diferencia de $A F, A V$ adopta una estructura más parecida a la sintaxis de la tragedia clásica, aunque, como reconoce Javier de Navascués (1998), la resolución no pueda presumirse como estrictamente trágica por carecer del "sentimiento de abandono metafísico" (p. 18) propio de este género dramático. Plagada de descripciones poéticas y símbolos de provechosa significación, la estructura de $A V$ es copiosa en recursos y elementos apenas dibujados en el texto sofocleo, con intervenciones muy al estilo del Marechal poeta. La acción se desarrolla en "La Postrera", en algún lugar de las pampas argentinas durante el siglo XIX. El padre de los Vélez (Edipo) ha muerto "sableando infieles" en la costa del Salado, mientras Lisandro (Hemón), enamorado de Antígona, encuentra mayor cabida e importancia en esta versión. La lectura atenta del mito clásico permite al autor intervenir y actualizar tres cuestiones fundamentales: la transposición de 
Tiresias en las brujas, la fuerte unión de los amantes y la conversión del suicidio de Antígona en homicidio. Su muerte no será ahora consecuencia de la transgresión a la ley de Creonte, sino que recaerá en manos de los indios pampas. Acaecida la muerte de los amantes, en el cuadro final, las brujas relatan:

BRUJA 2 $2^{\mathrm{a}}$ : (Descontenta) ¡Había en el campo dos muertos que sobraban!

BRUJA $3^{a}:$ ¿Sobraban dos muertos?

BRUJA 2a: ¡Un hombre y una mujer! Y entre los dos formaban, contra el odio, un solo corazón partido (Marechal 1998, p. 71).

La idea del homicidio es el elemento de $A V$ en que se observa el mayor desplazamiento de la carga temática y su transposición ideológica; en otros términos, si en la versión clásica preexiste la decisión expedita en Antígona de darse muerte, y en Hemón de morir en la cueva junto a ella, en $A V$ la muerte de los amantes recae no obstante en la lanzada de los pampas. La cueva se sustituye por "una carrera con la muerte", y los amantes son ahora atravesados por la misma lanza. Al desdibujarse el acto suicida, se restauran además la moral y la ética del discurso judeocristiano.

Para Marechal, los muertos "pesan" distinto que para Gambaro. La reconstrucción de un espacio y un tiempo anteriores - la Argentina de Juan Manuel de Rosas, de la civilización y la barbarie de Sarmiento- resignifica las muertes "sobradas" de Antígona y Lisandro sobre la llanura: en este regreso, Marechal siembra el germen de un nuevo mito fundacional argentino, en el que la muerte de una pareja primigenia y edénica promoverá una progenie renovada. Estos hombres y mujeres nuevos, dice el personaje Facundo Galván, "algún día cosecharán en esta pampa el fruto de tanta sangre" (1998, p. 74). La muerte de la otra Antígona, la furiosa, por el contrario, es colectiva: "No fue Dios quien la dictó ni la justicia. (Ríe) ¡Los vivos son la gran sepultura de los muertos! ¡Esto no lo sabe Creonte! ¡Ni su ley!" (Gambaro 1989, p. 202). Justo en el medio de la muerte de estas dos Antígonas se encuentra lo que Steiner señalaba como una característica del mito, que es la distinción entre lo público y lo privado, entre el individuo y la comunidad: la de Antígona Vélez, la mártir, se ordena como una muerte pública en favor de un proyecto de nación; la de la otra Antígona, la furiosa, se multiplica para abarcar en ella los casos íntimos e 
individuales de otras Antígonas, otros Polinices. Por ello, la certidumbre marechaleana no tiene cabida en Gambaro.

Precisamente en torno a los vaticinios parciales y sus expresiones sobre la muerte "sobrada" de los amantes, Javier de Navascués explica que "Marechal quiere dar algunas pistas para desentrañar un mensaje que nada tiene del fatalismo griego y sí mucho del optimismo histórico cristiano" (1998, p. 18). Esto podría explicar "el bárbaro sacrificio de los amantes", y la muerte de la heroína como un concilio, una ofrenda: "porque Antígona debe morir para que se cubra de flores el desierto" (Marechal 1998, p. 68). Si en $A V$ el sacrificio por amor es un reclamo de esperanza, $A F$ debería situarse, más bien, entre el amor y el odio, como en un arrebato amoroso que se anuncia desde su epíteto. Abatida por la burla y la falsa misericordia de Creonte, Antígona se revela tal como la heroína sofoclea en uno de los diálogos más poderosos y emotivos de la obra de Gambaro, citados anteriormente: una heroína nacida para compartir el amor, a pesar del triunfo del odio y la ruptura de toda esperanza (el silencio).

Para Marechal, la sangre y las lágrimas que han de llenar de flores el desierto, tanto en el presente como en el futuro de la pampa, son las derramadas por y para los amantes. La locura de la heroína clásica se desdibuja, aunque no el nefas, que se transfigura en sacrificio de amor maternal. Así, no sólo se desvanece la genealogía incestuosa con el desplazamiento de Yocasta fuera del relato, sino que además se suprime con ello la noción de la hamartia que recae sobre todos los labdácidas. Sin la supresión del "error trágico" no podría comprenderse la reelaboración que Marechal hace del mito en función del proyecto de nación que propone en su Antígona, y que de alguna manera se alimenta del optimismo justicialista del peronismo. En $A F$, caso contrario, las únicas flores serán aquellas marchitas en la corona de Antígona: su sacrificio no será el humus de la pampa, ni de su sangre en el suelo crecerán flores, como sí ocurriría -según recuenta el poeta Páncrates de Alejandría- con el bitinio Antinoo (de antheo, 'el que florece'), herido durante la caza de un león, y de cuyo humor derramado brotaría la flor que lleva su nombre (antinóeios).

Las intervenciones que llevan a cabo Marechal y Gambaro de la tragedia de Sófocles son múltiples como variadas. Encontrar distancias entre las obras responde, desde luego, al horizonte ético y estético desde el cual cada autor escribe, y las 
cercanías o continuidades, como se ha visto, son producto de la apropiación de un tema que ha logrado adaptarse a diferentes tradiciones y contextos sociopolíticos. La fuerte impronta de la pampa en la recreación del mito griego sirve al escritor argentino "con el firme propósito de «universalizar las esencias nacionales»" (Navascués 1998, p. 18); en cambio, en la obra de Gambaro, tal parece que el sentido es inverso: "Es y no es exactamente la Antígona de Sófocles, desde luego", dice la autora porteña, "mis obras pueden transcurrir en la Grecia Antigua o en la Francia de 1700, pero la mirada es la mirada de una argentina, porque los datos de mi experiencia son los de la realidad de mi país. Cuando uno escribe teatro o ficción hace uso de su memoria y de la memoria colectiva de su propio entorno" (en Roffé 1999, p. 114). La suya es una propuesta sobre cómo entrever, en la universalidad atemporal del relato, la contemporaneidad del acontecer político y social.

\section{DECIR SIEMPRE LO IMPORTANTE}

La persistencia del mito de Antígona en distintos imaginarios culturales demuestra su cualidad de topos de longue durée. Por un lado, la versatilidad del tema para adaptarse a distintos contextos conflictivos se debe principalmente, como indica George Steiner (2009), a cinco condiciones que son indisociables entre sí: el conflicto entre lo privado y lo público, la confrontación entre las leyes divinas y las humanas, las fricciones entre el Estado y la familia, la razón privada frente al bienestar público y el legalismo coercitivo frente al humanismo instintivo (pp. 55 y 100). El resurgimiento y auge del relato clásico, por otro lado, se debe a tres causas capitales: las adaptaciones y traducciones que se hacen del texto en 1530 más la difusión de Le Voyage du jeune Anarchasis (1788), del abate Jean-Jacques Barthélemy, novela en que se detalla el arrebato de su joven protagonista ante la pieza clásica; el interés simultáneo que el mito suscitó en Hegel, Hölderlin y Schelling durante el siglo XviII; y la famosa representación del texto que Goethe organizó el 28 de octubre de 1841, bajo la dirección de Ludwig Tieck (Steiner 2009, pp. 21-23). Una cuarta razón se asoma en su ensayo, aunque, dice, probablemente sea menor: el entierro de personas aún con vida, tema que "sojuzga y domina las imaginaciones de fines del siglo XVIII y principios del XIX” (p. 33). 
Esta última causa, como se constató en $A F$, forja una marca indeleble que efectivamente se asocia con la revivificación y reelaboración de la Antígona durante períodos de agitación social y política ${ }^{22}$. Griselda Gambaro también actualiza una Antígona ceñida, por obvias razones, a un fondo histórico y social que no se desglosa llana y directamente en el texto; sin embargo, provoca, por medio de las distintas pistas que siembra en la escritura, la sensación de continuidad y vigencia según temas contemporáneos y, al mismo tiempo, lejanos, insertos en una larga tradición:

Esta Antígona no es la adaptación ni la versión de la Antígona de Sófocles. Ciertas obras no lo permiten sin que el intento caiga en la pretensión. Antígona furiosa toma el tema de Antígona, entresaca textos de la obra original y de otras obras, arma una nueva Antígona fuera del tiempo para que paradójicamente nos cuente su historia en su tiempo y en el nuestro (Gambaro, apud Contreras 1994, p. 143) ${ }^{23}$.

Y ante la gran deuda de Steiner con la tradición latinoamericana, Rómulo Pianacci dedica por su parte un arrojado pero puntual estudio sobre el mito desde la dramaturgia con obras publicadas, o sólo representadas pero inéditas, entre 1951 y 2014. Según el crítico, en Argentina encontramos catorce Antígonas $^{24}$, en México se registran cinco, en Cuba se escriben cua-

${ }^{22}$ Recordemos, en este sentido, tan sólo algunas de las versiones europeas escritas en el siglo xx, de amplia difusión en Latinoamérica, y que se enmarcan por períodos de guerra y posguerra. La primera de ellas, en 1922, de Jean Cocteau, seguida en 1939 por la de Salvador Espriu, en 1944 por la de Jean Anouilh, en 1948 por la de Bertolt Brecht, y en 1955 por la de José Bergamín. La sangre de Antígona, de Bergamín, se escribe durante su exilio en París, en 1955, pero se publicaría hasta 1983, en Primer Acto. Posteriormente, la primera representación de la que se tiene registro tendría lugar en 1996, a cargo del director Guillermo Heras, en la Facultad de Teatro de la Universidad de Cuyo, en Argentina.

${ }^{23}$ Este fragmento formó parte del texto que Gambaro incluyó como introducción en el "Programa" para el estreno de la obra.

${ }^{24}$ Las nombro por orden de escritura: Antígona Vélez (1951) de Leopoldo Marechal; El límite (1958) de Alberto Zavalía; Antígona furiosa (1986) de Griselda Gambaro; La cabeza en la jaula (1987) de David Cureses; Golpes a mi puerta (1988) de Juan Carlos Gené; In memoriam Antigonce (1999, inédita) de Rómulo Pianacci; Antígonas: linaje de hembras (2001) de Jorge Huertas; Antígona... con amor (2003) de Hebe Campanella; Antígona, ¡no! (2003, inédita) de Yamila Grandi; Antígona Hot (2009, inédita) de Antonio Celico y Manuel 
tro, en Uruguay, Venezuela, Chile, Perú y Colombia se tiene conocimiento de dos en cada caso, y finalmente están Nicaragua, Puerto Rico, Brasil y República Dominicana con una Antígona en cada país ${ }^{25}$. Pero a pesar del gran esfuerzo por crear un largo inventario sobre las Antígonas en América Latina, las conclusiones que Pianacci ofrece sobre las piezas de Marechal y Gambaro se antojan limitadas:

Marechal con un echeverriano romanticismo tardío o "neocriollismo" encaja dentro de los moldes de un costumbrismo de cartón-piedra, con gauchos ladinos y patrones benevolentes que bailan el pericón, descritos por el cine de Buenos Aires o el "melodrama norteño" de Juan Oscar Ponferrada con El Carnaval del Diablo. La Gambaro, treinta y siete años más tarde, maniobra de igual manera al estructurar una obra de acuerdo con operaciones transtextuales del teatro offo under, a esta altura ya canónico, que

Longueira; Antígonas (2009, inédita) de Alberto Muñoz; Antígona fantasma (2013, inédita) de Daniel Fermani; Antígona en sintonía (2013, inédita) de Adrián Giampagni; y Antígona 1.11.14 del Bajo Flores (2013, inédita) de Marcelo Marán.

${ }^{25}$ Quedará pendiente ampliar este coro trágico con otras Antígonas, desde la poesía, la narrativa, el ensayo, la performance $\mathrm{u}$ otros registros artísticos. Por poner tan sólo un ejemplo, la Antígona González, escrita en 2012 por la mexicana Sara Uribe: en su novela con licencia copyleft, Uribe se apropia del mito clásico para relatar literariamente el hallazgo de setenta y dos cuerpos de migrantes centroamericanos en San Fernando, Tamaulipas, en 2010, con el propósito de visibilizar a las víctimas de la llamada "guerra contra el narco" y para evidenciar la perversa lógica de la necropolítica actual. Entre sus páginas, asimismo, Uribe alude a las Antígonas de Marechal y de Gambaro, muestra de que el tema trágico es motivo de diálogo, continuidad y sintonía en términos artísticos, pero también políticos. El horizonte al que hace referencia $A F$ es, desde luego, el de la dictadura. Pero también refleja las condiciones de un período marcado por una estricta censura cultural y artística ("listas negras", clausura de teatros, persecución y desapariciones, requisa y quema de libros), o la prohibición expresa de autores y artistas considerados "subversivos". El conflicto por las Islas Malvinas en 1982 fue el último destello beligerante de "El Proceso" antes de su término en 1983. Los años inmediatos a la posdictadura supusieron el recrudecimiento de las protestas civiles para dar voz a las víctimas, en medio de una frágil vuelta a la democratización. Un reconocido primer intento por visibilizar el crimen de Estado se materializó en el libro Nunca más, también conocido como "Informe Sábato" - por ser el escritor Ernesto Sábato quien liderara la Comisión Nacional sobre la Desaparición de Personas- en 1984, que investiga y documenta la violación sistemática de los derechos humanos con el fin de "indagar la suerte de los desaparecidos en el curso de estos años aciagos de la vida nacional" ("Prólogo", en SÁbato 1984, p. 7). 
articulan al legendario Instituto Di Tella..., con Batato Barea, pasando por las obras de Emeterio Cerro, el dúo Urdapilleta / Tortonese y el Parakultural (2015, pp. 101-102) ${ }^{26}$.

Si bien es cierto que la temporalidad de $A V$ sitúa la acción durante el período sarmientino y rosista, ello no implica un "echeverriano romanticismo tardío" o una propuesta estética desfasada, sino todo lo contrario: la actitud de Marechal, su relectura de la historia y de un proyecto de nación a partir del mito clásico podría asociarse más con las enseñanzas de uno de sus maestros, Alfonso Reyes, quien relee a los clásicos y los mitos antiguos en la historia nacional mexicana-de ahí el "universalizar las esencias nacionales", que señalaba atinadamente Navascués. Hay que agregar que esto también acerca a Marechal a los distintos debates sobre el ser nacional de las décadas de 1940 y 1950, debates que se sostuvieron en toda Hispanoamérica.

Sobre el contexto que refiere Pianacci en torno a $A F$, algunos apuntes más. La dramaturgia de Gambaro nace y se nutre del Di Tella en los años sesenta, sí, pero la década de 1980 supuso constreñidas condiciones culturales tanto para la autora como para el Instituto, momento en que ella colaboró más bien con Teatro Abierto (1981-1983), al regreso de su exilio. Durante el tiempo de Teatro Abierto, movimiento "de clara connotación política" que para Gambaro "fue teatro y algo más que teatro" (en Arancibia y Mirkin 1992, p. 228), la escritora participó con la obra Decir sí (1981); en cambio, poco o nada se dice sobre su participación, si acaso la hubo, con Parakultural, centro multidisciplinario underground conocido también por su incursión artística a mediados de los años ochenta y hacia los noventa. Es decir, las circunstancias que rodean la propuesta gambariana y la de sus contemporáneos en los años setenta y ochenta configuran un tipo de teatro reactivo, y sólo en ese sentido "menos visible”, a causa de la censura y la persecución del Estado. Por

${ }^{26}$ Los artistas aludidos por el crítico -Barea, Cerro, Urdapilleta y Tortonese- fueron reconocidos por su adhesión al Centro Parakultural y a otros sitios no convencionales en los que llevaban a cabo sus propuestas. Se trata, particularmente, de una generación de escritores, actores y performers argentinos nacidos entre los años cincuenta y los años sesenta, y, hasta donde se tiene registro, no colaboraron con Griselda Gambaro. La comparación entre estas generaciones (o entre el Di Tella y el Parakultural, vigentes en décadas distintas), así como el ánimo "tardío" que Pianacci señala en Gambaro y en Marechal, en este sentido, nos parecen sobrados. 
último, lo que Pianacci entiende en Gambaro como una operación transtextual "tardía" ("treinta y siete años más tarde", dice) es producto de ignorar los procedimientos reescriturales que la autora emplea a lo largo de toda su obra, y que no son sólo una expresión de los años ochenta.

En las palabras finales de Pianacci, especialmente en el fragmento citado sobre Gambaro, se perciben más bien los argumentos de otra voz: la del dramaturgo y actor porteño Rafael Spregelburd ${ }^{27}$. En un álgido debate que Gambaro y Spregelburd sostuvieron en 2007, la dramaturga lo criticó duramente después de que aquél afirmara que su "generación ha logrado recuperar una situación gozosa del teatro, liberado del imperativo de «decir lo importante»" (en Rodríguez Ballester 2007, s.p.), refiriéndose al teatro de los años ochenta. La respuesta abierta de Gambaro explica cómo concibió -y aún concibe en su producción actual- su teatro durante los años en que escribe $A F$ :

El teatro es muchas cosas, entre ellas ideológico... También la ideología nos revela cuando rechazamos "decir lo importante". Que se haga bien o mal es otro asunto. El teatro es una experiencia lúdica, pero el juego se banaliza si callamos lo importante como un valor que la sociedad no necesita (Gambaro 2015 [2007], pp. 1730-1735).

27 Remito a las declaraciones que Spregelburd hiciera públicas el 12 de mayo de 2007, en una nota titulada "La importancia de llamarse teatro", para el diario Clarín, en Buenos Aires: "Es muy difícil que las generaciones se entiendan. Más bien tratan de aleccionarse unas a otras. O más bien hay una generación que siempre trata de aleccionar a la otra. Yo lo sé en carne propia, y no es tema que me apasione: nos llaman «teatro joven», nos quieren transferir los modelos que sirvieron para ellos. Es un síntoma evidente de vejez. La vejez no es ni buena ni mala, es natural, y yo estaré allí algún día. Pero no hoy. Hoy veo que estas correcciones que se me quieren hacer implican un retroceso enorme, como cuando en los 80 muchos autores de prestigio se burlaban de Batato Barea o de Alejandro Urdapilleta, o despreciaban el fenómeno Parakultural" (s.p.). Léase asimismo la adenda que el crítico de teatro Jorge Dubatti publica sobre el mismo tema, el mismo día, también para Clarín, bajo el título "Un lamentable malentendido": "Todos amamos a Griselda Gambaro. Todos respetamos su obra incondicionalmente... Justamente, por todo esto, nos permitimos creer que la nota de $\tilde{N}$ que ella firma el sábado pasado, sencillamente no es de ella. Esta no es Griselda. «La Gambaro» no pudo escribir eso [sobre Spregelburd]... Ojalá Griselda decida no incluir [esta discusión] en sus radiantes obras completas" (s.p.). 
Esta noción de lo importante en los años ochenta es el resultado de una insignia que comienza a forjarse desde los años sesenta, en el marco de una violencia generalizada (la dictadura de Onganía, "El Cordobazo", protestas sindicales y estudiantiles, represiones militares, guerrillas urbanas), momento en que la huella distintiva de la producción dramática argentina fue la politización del teatro: ya desde el realismo o la neovanguardia del teatro de recinto, ya desde los precursores del caféconcert, hasta los contingentes teatrales militantes que acercaban el arte escénico al conurbano bonaerense y otras provincias. Los subsecuentes años setenta, los llamados "años de plomo", vieron al heredero teatro politizado madurar hacia propuestas estéticas más pujantes y reactivas, aún a pesar de las censuras, las "listas negras", y a pesar incluso de los exilios o las desapariciones forzadas. Estas condiciones -los mecanismos represivos y la politización del teatro- fueron las grandes fuerzas de una dramaturgia que "se vio obligada a metaforizar en atención tanto a la posible censura exterior como a una previsora autocensura interna" (Fernández 1992, p. 49). Este enmascaramiento templó un tipo de "lenguaje elíptico", sostiene Gerardo Fernández, pues efectivamente la realidad se envolvió ingeniosamente con símbolos y analogías, signos codificados y articulados de manera tal que su sentido no languideciera ante el ojo del público receptor.

La obra de Gambaro no fue la excepción durante los años en que tuvo mayor efecto este enmascaramiento del arte. De ahí, también, que las lecturas críticas tiendan siempre a la interpretación politizada y la exposición de analogías entre texto y contexto. Lectura innegable, por cierto, tanto como necesaria, pero básica; básica, porque evidentemente cimenta una plataforma sólida desde la cual el imperativo se vuelve, a su vez, otro: desvelar cuáles son las sintonías que subyacen, diacrónicamente, en esta constelación de textos puestos en diálogo. A partir de Sófocles y su Antígona, Gambaro reconoce también el largo alcance, a través del tiempo, de ese mito que conlleva algunos de los conflictos más hondamente humanos:

Pero esa responsabilidad [con el presente] abarca también ocuparse de aquellos temas que han acuciado a la humanidad desde el origen de los tiempos, los que preocuparon a Sófocles, Shakespeare, Brecht, Beckett. Los temas de Antígona, Rey Lear, Galileo Galilei, Esperando a Godot; la justicia y el desafío al poder, la ambi- 
ción y el abandono, el conflicto con la verdad, el deseo que se consume en la espera (Gambaro 2015 [2007], p. 1721).

De la misma manera, Kierkegaard advirtió cómo el tema clásico desvanece las fronteras entre la vida y la muerte, y se pregunta: “ ¿No se siente uno poseído de cierta amargura cuando considera que, a pesar de que el mundo esté cambiando, la representación de lo trágico ha permanecido inmutable en su agenda, como inmutable se conserva ese don, natural en el hombre, de verter lágrimas?” (2003 [1843], pp. 10-11). La Antígona furiosa de Gambaro reúne en un solo caudal las voces de sus homólogas (la de Sófocles, la de Yourcenar), para configurar un personaje igualmente proteico, que asimila en sí otros relatos y personajes afines como Ofelia, Hamlet y Antinoo. Como lo demuestran sus reescrituras, el teatro de Gambaro busca "decir lo importante" dialogando con una larga tradición literaria, cultural, y a la vez, con su entorno inmediato en un reiterado asedio a lo más elemental y simultáneamente universal del ser social.

La escritura gambariana se fundamenta en el comentario crítico sobre otras obras, incluso la obra propia. Y quien se apropia citando enfrenta invariablemente la "contradicción entre escritura social y apropiación privada", experimenta los cambios de función textual de lo que parodia (cambios atravesados "por el cruce entre la literatura y la sociedad"), para lo cual requiere "reconstruir en primer lugar las condiciones históricas, sociales e ideológicas que hacen posible el cambio que la parodia vendría a expresar" (Piglia 2014, pp. 42-43). Las reescrituras exigen siempre una voluntad de continuidad, pero también de transformación, invitan al reconocimiento de influencias y distanciamientos, porque el escritor debe imponerse ante todo como un lector voraz: "Yo siempre digo que empecé a escribir cuando empecé a leer" (Gambaro, en Durañona 1992, p. 408). La crítica no ha sido ajena a esta forma peculiar de escritura en sus obras, una propuesta artística que va más allá del simple desvelamiento de influencias o fuentes literarias. Entender estos entretejidos y estas imbricaciones discursivas como un tipo de "mestizaje cultural" nos resulta una figura iluminadora al momento de adentrarnos en los ceñidos procedimientos de identificación y distinción, de recreación transgresora en su poética. Esta peculiar noción (la de "mestizaje cultural"), precisamente la recobramos a partir de la 
concepción de la propia autora acerca de la pieza central que estudiamos aquí, su Antígona furiosa:

Sí, creo que en esta pieza es donde el mestizaje cultural se hace más evidente. De cualquier forma, Antígona es un personaje del que se han apropiado en todas partes. Los griegos dieron mucho de sí. Pero nuestra manera de apropiarnos es muy diferente a la de los creadores que producen en los grandes centros culturales... Los argentinos no nos podemos dar ese lujo, porque no tenemos el tiempo ni las condiciones económicas para dedicarnos a investigar. Entonces, tomamos un atajo; usamos, si se quiere, nuestra ignorancia y lo que sabemos. A partir de ahí, imaginamos e inventamos otra cosa para hablar de nuestra propia realidad... Es y no es exactamente la Antígona de Sófocles, desde luego (en Roffé 1999, pp. 113-114).

Su Antígona proviene del mestizaje, del conocimiento crítico de las condiciones sociales y culturales que motivan la apropiación y el "cambio" del texto reescrito, pero también proviene de la voluntad de que sea "otra cosa" para hablar de la realidad presente. Para Gambaro, y retomando sus propias palabras, este largo proceso de apropiación que recorre sus obras es un proceso en el que está en juego el "imaginar" e "inventar" "otra cosa para hablar de nuestra propia realidad". Hay en ese gesto reiterado una clara voluntad de revaloración, transformación, adaptación e integración tanto textual como contextual. Y tal como la metáfora sociológica y política, incluso filosófica, lo demanda, no podríamos comprender este "mestizaje" sin antes verlo como un hecho complejo, sistémico, multifactorial, en ocasiones problemático, en cuya sinergia se templa una visión para afrontar y descifrar el acontecer del mundo.

Todo discurso escrito desde estos ingenios reescriturales se comporta como un atlas de viaje, donde el conjunto de sus elementos semejantes contribuye a la proyección de un destino. Pero visto en singular, su valor es mayor a la suma de todas sus partes, y mayor todavía a una simple larga lista de obras y autores apropiados. No es, por lo tanto, en Gambaro un mecanismo expropiador y acumulativo, sino la marca de una voluntad conciliadora. Como narradora, dramaturga, crítica y ensayista, la escritora busca desentrañar su presente desde los asedios de la palabra. Gambaro, lectora perspicaz, generosa escritora, nos hace entrega así de su lectura cartográfica del devenir 
humano: impulsada un tanto por la prístina guía del mundo, que es el arte, y otro tanto por la agudeza de su invención.

\section{REFERENCIAS}

Abel, Lionel 1969. Metatheatre. A new view of dramatic form, Hill \& Wang, New York.

Arancibia, Juana y Zulema Mirkin 1992. "Introducción”, en Teatro argentino durante el Proceso (1976-1983). Ensayos críticos y entrevistas. Eds. Juana Arancibia y Zulema Mirkin, Editorial Vinciguerra-Instituto Literario y Cultural Hispánico, Buenos Aires. (Colección Estudios Hispánicos, 2).

Bergua Cavero, Jorge 1982. "Introducción”, en Sófocles, Tragedias. Trad. de Assela Alamillo, rev. por Carlos García Gual, Gredos, Madrid, pp. i-xxxii.

Brecht, Bertolt 1963 [1954]. "Intimidation par les classiques", Écrits sur le thêâtre, L'Arche, Paris, pp. 577-579.

Compagnon, Antoine 1979. La seconde main ou le travail de la citation, Éditions du Seuil, Paris.

Compagnon, Antoine 2015 [1998]. El demonio de la teoría. Literatura y sentido común. Trad. Manuel Arranz, Acantilado, Barcelona.

Contreras, Marta 1994. Griselda Gambaro. Teatro de la descomposición, Ediciones Universidad de Concepción, Concepción.

Domínguez, María Alicia 1953. Niños felices. Libro de lectura para primer grado superior, Editorial Kapelusz, Buenos Aires.

Dubatti, Jorge 1999. "El teatro como crítica de la sociedad", en Historia crítica de la literatura argentina. Dir. Noé Jitrik. T. 10: La irrupción de la crítica. Dir. Susana Cella, Emecé Editores, Buenos Aires, pp. 259-273.

Dubatti, Jorge 2007. "Un lamentable malentendido", Clarín, Buenos Aires, (sec. "Espectáculos: Debate") 12 de mayo, en t.ly/owh9 [consultado en marzo de 2017].

Durañona, Marina 1992. "Entrevista con Griselda Gambaro", Alba de América, $10,18 / 19$, pp. 407-418.

FERnÁndez, GERARDo 1992. "Historias para ser contadas", en Teatro argentino contemporáneo. Antología. Dir. Moisés Pérez Coterillo. Coord. Gerardo Fernández, Fondo de Cultura Económica, Madrid pp. 13-63.

Gambaro, Griselda 1989. Teatro 3, Ediciones de la Flor, Buenos Aires.

Gambaro, Griselda 1999. Escritos inocentes, Norma, Buenos Aires.

Gambaro, Griselda 2015 [2007]. "Decir lo importante”, en El teatro vulnerable, Alfaguara, Buenos Aires, pp. 1708-1740. [Versión para Kindle].

Genette, GÉrard 1989 [1982]. Palimpsestos. La literatura en segundo grado. Trad. Celia Fernández Prieto, Taurus, Madrid.

Guillén, Claudio 1985. Entre lo uno y lo diverso. Introducción a la literatura comparada, Crítica, Barcelona.

KierkegaArd, Søren 2003 [1843]. Antígona. Trad. Juan Gil-Albert, Renacimiento, Sevilla. 
Kristeva, Julia 1997. "Bajtin, la palabra, el diálogo y la novela”, en Intertextualité. Francia en el origen de un término y desarrollo de un concepto. Comp. Desiderio Navarro, UNEAC, Casa de las Américas, La Habana, pp. 1-24.

Lafon, Michel 1990. Borges ou la réécriture, Éditions du Seuil, Paris.

Llurba, Ana María 1998. “Antígona furiosa, ¿una voz femenina?”, Gramma, 10, 30, pp. 20-31.

Marechal, Leopoldo 1998. Obras completas. T. 2: El teatro y los ensayos, Perfil Libros, Buenos Aires.

Moset, Ulises 2017. "El teatro rosarino como fuerza movilizadora de la memoria sobre la última dictadura", La Capital, Rosario, (sec. "Escenario") 23 de marzo, en t.ly/YwaL [consultado en marzo de 2017].

NAVASCUÉs, JAVIER DE 1998. "Réquiem por un teatro incompleto", en Leopoldo Marechal, Obras completas. T. 2: El teatro y los ensayos, Perfil Libros, Buenos Aires, pp. 11-27.

Parra de Ruiz de los Llanos, Mabel 2001. "De Sófocles a Gambaro: historia del poder", Cuadernos de la Facultad de Humanidades y Ciencias Sociales. Universidad Nacional de Jujuy, 16, pp. 123-131.

Pellettieri, Osvaldo 1997. Una historia interrumpida. Teatro argentino moderno (1949-1976), Galerna, Buenos Aires.

Pérez Gómez, Leonor 2011. “Observaciones sobre las pasiones en la estructura profunda de las tragedias de Séneca: importancia e interpretaciones del furor", Florentia Iliberritana, 22, pp. 149-168.

Perón, Juan Domingo 1958. La fuerza es el derecho de las bestias, El Soberano, Buenos Aires, versión para Kindle.

Pianacci, Rómulo 2015. Antígona: una tragedia latinoamericana, Losada, Buenos Aires.

Piglia, Ricardo 2014. "Parodia y propiedad", en Crítica y ficción, Debolsillo, Barcelona, pp. 40-43. [Versión para eBook].

Pimentel, Luz Aurora 1993. "Tematología y transtextualidad”, Nueva Revista de Filología Hispánica, 41, pp. 215-229; doi: 10.24201/nrfh.v41i1.931.

Pimentel, Luz Aurora 2012. Constelaciones. T. 1: Ensayos de teoría narrativa y literatura comparada, Iberoamericana, Madrid.

Poniatowska, Elena 1991. "Mujer y literatura en América Latina", en Los novelistas como críticos. Comps. Norma Klahn y Wilfrido Corral, Fondo de Cultura Económica, México, pp. 308-317.

Reato, Ceferino 2014. "Cuando Perón rompió con Montoneros", Clarín, Buenos Aires, (sec. "Política") $1^{\circ}$ de mayo, en t.ly/7IGN [consultado en marzo de 2017].

Reisz, Susana 1995. "Antígona entre el amor y el furor (o Griselda Gambaro ante el viejo Sófocles)", Synthesis, 2, pp. 93-106.

Rodríguez Ballester, Alejandra 2007. "Entrevista a Rafael Spregelburd", Revista N, Clarín, Buenos Aires, 14 de abril.

Roffé, Reina 1999. "Entrevista a Griselda Gambaro", Cuadernos Hispanoamericanos, 588, pp. 111-124.

SÁbato, Ernesto 1984. Nunca más. Informe final de la Comisión Nacional sobre la Desaparición de Personas, Editorial Universitaria de Buenos Aires, Buenos Aires. 
Shakespeare, William 2015 [1609]. Hamlet. Ed. bilingüe del Instituto Shakespeare dirigida por Manuel Ángel Conejero Dionís-Bayer, con introd. de Cándido Pérez Gállego, Cátedra, Madrid.

Sicot, Bernard 2011. Reseña de "Rose Duroux et Stéphanie Urdician (eds.), Les Antigones contemporaines (de 1945 à nos jours)", Bulletin Hispanique, 113, 2, pp. 816-821; doi: 10.4000/bulletinhispanique.1480.

Sófocles 2002. Antigone. Éd. bilingue. Trad. Paul Mazon. Postfacier Nicole Loraux, Les Belles Lettres, Paris.

Spregelburd, RAFAel 2007. "La importancia de llamarse teatro", Clarín, Buenos Aires, (sec. "Espectáculos: Debate") 12 de mayo, en t.ly/ppSE [consultado en marzo de 2017].

Steiner, GEORGe 2009. Antígonas. La travesía de un mito universal por la historia de Occidente, Gedisa, Barcelona.

Teixidó, Lucrecia y Sergio Bufano 2015. Perón y la Triple A. Las 20 advertencias a Montoneros, Editorial Sudamericana, Buenos Aires.

Vilanova, Ángel 1999. "Nuevas aproximaciones a las Antígonas iberoamericanas”, Nueva Revista de Filología Hispánica, 47, pp. 137-150; doi: $10.24201 /$ nrfh.v47i1.2618.

Yourcenar, Marguerite 1974. Mémoires d'Hadrien, Gallimard, Paris.

Yourcenar, Marguerite 2016. Cuentos completos, Penguin Random House, Barcelona. 
